\title{
學振における電刷子研究の業績 (5)
}

\author{
學振第 117 委員會委員長 宗 宮 知 行 \\ (Research Works on Carbon Brushes in Japan \\ Research Promotion Society) \\ (TomoKuki Somiya)
}

前號まで

（1）緒言（2）業績の全貌（3）炭素刷子の物理的特性 並に測定法 a. 比重 b. 彈性係數 c. 摩擦係數 $d$. 衝 㢣耐力 e.H.D.R 特性 f. 整流試驗 g. 固有批抗, 硬度及で抗折力

\section{h. 物理的諸性啠の測定值}

各檑刷子の物理的特性值が澤山委員會飞提出さ れた。测定方法が同一でない事が主己して原因し て，同一品名の資料飞對して子可成り雜多な值が

Table 1.

\begin{tabular}{|c|c|c|c|c|c|c|}
\hline Brush Mark & $\begin{array}{l}\text { Hardness } \\
\text { Shore }\end{array}$ & $\begin{array}{l}\text { Breaking } \\
\text { Strength } \\
\mathrm{kg} / \mathrm{cm}^{2}\end{array}$ & $\begin{array}{l}\text { Sp. Resist } \\
\Omega \mathrm{cm} \times 10^{-4}\end{array}$ & $\begin{array}{l}\text { Elasticity E } \\
\mathrm{kg} / \mathrm{cm}^{2} \times 10^{3}\end{array}$ & $\begin{array}{c}\text { True } \\
\text { Density }\end{array}$ & $\begin{array}{c}\text { Apparent } \\
\text { Density }\end{array}$ \\
\hline $\mathrm{SA}-45$ & 38 & 104 & 70 & 47 & 1.988 & 1.50 \\
\hline $\mathrm{SA}-40$ & 42 & 131 & 62 & 54 & 1.989 & 1.54 \\
\hline $\mathrm{SA}-35$ & 44 & 152 & 60 & 63 & 1. 979 & 1.55 \\
\hline $\mathrm{SA}-30$ & 46 & 192 & 55 & 69 & 1. 973 & 1.58 \\
\hline $\mathrm{SA}-25$ & 53 & 300 & 51 & 87 & 1. 993 & 1. 63 \\
\hline $\mathrm{TA}-45$ & 42 & 86 & 70 & 45 & 1.970 & 1.51 \\
\hline $\mathrm{TA}-40$ & 42 & 102 & 70 & 50 & 1.990 & 1.52 \\
\hline $\mathrm{TA}-35$ & 43 & 150 & 59 & 57 & 1. 970 & 1.52 \\
\hline $\mathrm{TA}-30$ & 50 & 212 & 55 & 62 & 1.980 & 1.56 \\
\hline $\mathrm{TA}-25$ & 55 & 310 & 50 & 83 & 1.990 & 1.57 \\
\hline NCC - 259 & 47 & 180 & 50 & 60 & 2.055 & 1.56 \\
\hline $\mathrm{NCC}-255$ & 53 & 212 & 46 & 83 & 1.990 & 1. 70 \\
\hline $\mathrm{NCC}-258$ & 40 & 280 & 20 & 93 & 2. 120 & 1.67 \\
\hline L 31 & 56 & 360 & 35 & 115 & 2.070 & 1.70 \\
\hline $8601 \mathrm{~N}$ & 60 & 430 & 39 & 120 & 1. 970 & 1.60 \\
\hline G E D & 45 & 300 & 18 & 100 & 2.210 & 1.70 \\
\hline 3398 & 57 & 250 & 42 & 70 & 1.980 & 1.66 \\
\hline USG 134 & 50 & 361 & 19 & 95 & 2.120 & 1. 74 \\
\hline$\oint 2600$ & 35 & 323 & 36 & 65 & 2.057 & 1.63 \\
\hline$\oint 2703$ & 50 & 280 & 55 & 80 & 2.000 & 1.58 \\
\hline$\oint 602$ & 43 & 82 & 80 & 35 & & 1. 45 \\
\hline$\bullet \mathrm{EG}-5$ & 52 & 300 & 30 & 100 & $2 \cdot 012$ & 1.68 \\
\hline (-) $\mathrm{EG}-9$ & 37 & 275 & 16 & 80 & 2. 160 & 1.76 \\
\hline - $\mathrm{EG}-\mathrm{GS}$ & 38 & 93 & 62 & 36 & 1. 955 & 1.47 \\
\hline - $\mathrm{EG}-\mathrm{AS}$ & 42 & 112 & 53 & 70 & 1. 950 & 1.60 \\
\hline • $\mathrm{EG}-41$ & 40 & 250 & 15 & 100 & 2.120 & 1.65 \\
\hline$\odot 1601$ & 40 & 170 & 34 & 50 & 2.050 & 1.67 \\
\hline$\odot$ EG 901 & 50 & 320 & 34 & 138 & 1. 980 & 1.75 \\
\hline • $) \mathrm{EG} 601$ & 33 & 80 & 73 & & 1.950 & 1. 45 \\
\hline YE 545 & 38 & 375 & 45 & & 1. 890 & \\
\hline
\end{tabular}




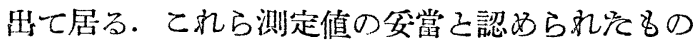
の本均值を示したものが第 1 表でする. 硬度は加 壓面己側面己で㤌異なる数值を示するのでするが その差異は加壓面同士の場合の差異に比適する程 度ですつをから，硬度としては此等兩面の平均值 を採用し\%。，又資料に上つては，發表されを测定

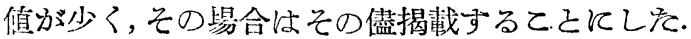

今緃軸に抗折力穔軸に硬变を取り明線を描いて 見る之第 29圖の㨾になる. A B 樣に沿ふものは ピッチコークスを主成分としをるので電驖用とし

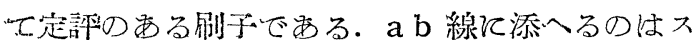

Fig. 29

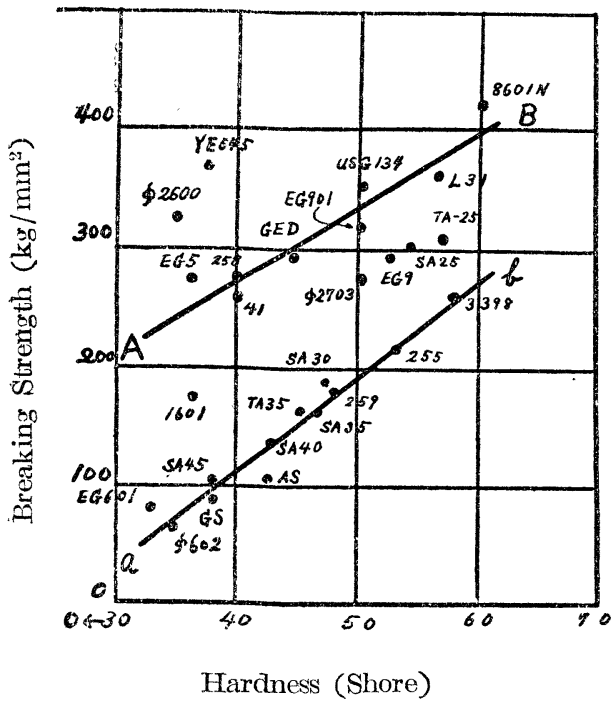

ートを主成分としをもので整流に重點を置んを刷

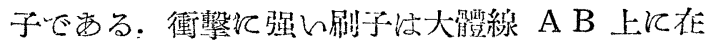
b，順序名略々抗折力の大さに從つて居る。

機械的に强々電鐵胕の別于は, 硬度 40 以上, 抗折力は $250 \mathrm{~kg} / \mathrm{mm}^{2}$ 以上の值を有して居る. 圖 から判る樣飞 AB 線己 $\mathrm{ab}$ 線さが比較的判然己

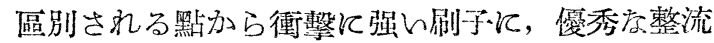
性能を附與する事㤝困難で西らう。硬度己固付抵 抗之の關係を第 30 圖飞示す. 此圖に於ても, ス 一ト系こコークス系こ方區分されて居る。 o a 線

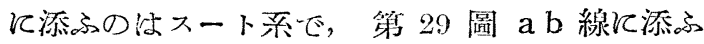
ものに相虽し， oA 亿添ふのはコークス系で第 29 圖 $\mathrm{AB}$ 線飞添ふコ一クス系に相當して居る。

スート系に屬して隻秀整流刷子は oa 線の近傍に コークス系に属して比較的整流のよい刷于蛙 oA

\section{素}

線の近傍に存在する。 o a 線の近傍にあるからと 言つて，その刷于がコークス系に虽するならば隹 秀刷子では舆々，一般に單に硬度．固有抵抗が同

Fig. 30

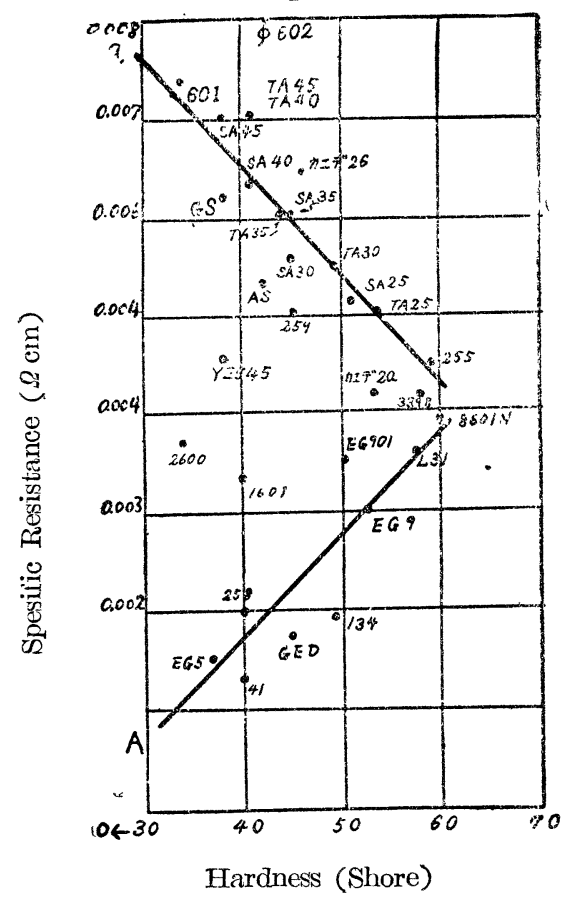

ビでも，その刷子は必秃しる優秀でない事が有り
Fig. 31

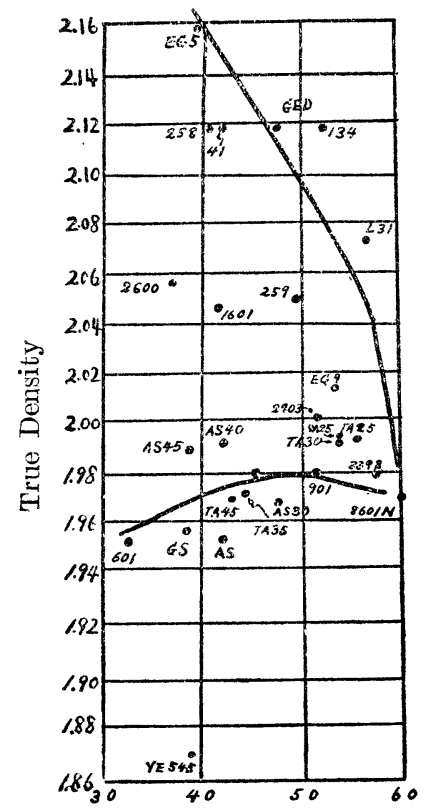

Hardness (Shore) 得る牙分泮るので 两つて, 從來硬信 固有抵抗が刷子判 笔の目安にならな レ己言礼て柬た 原因で西らう。

第 30 圖より整 流琵秀别子の硬度 惊 30 -60 无固有 抵抗は硬度により 異をるも，スート 系で络，0.008 オ 一 $\Delta \mathrm{cm}$ 加 0.004 オーム cm コークス系だは， 0.004 オーム cm から 0.001 オーム $\mathrm{cm}$ 苍必望之ずる。 
侗スート系では硬度が高い程固有抵抗が娍少し コークス系では硬度が高い程固有抵抗が㙫加して 居る。乙狄はコークス系とスート系己の特徵を表 はして居るので，スート系は熙鉛化が難かしく， 主己して粒接觸で. 粒己粒との接觸抵抗が固有抵 抗の大部分を占的るから，成形加壓が大き， 硬 度の高んもの涸諙抵抗が小さん.コークス系は 黑鉛化し易々，黑鉛化は黑鉛結晶の堆加成長家意 味するから，硬度引゙下る己其洫固有抵抗が低下す

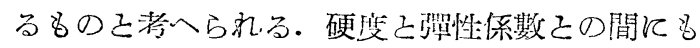
似它關係があるが，乙れ江省略して硬度已畺此重 との關係を第 31 圖に示す.

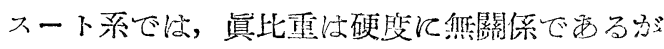
Fix. 32

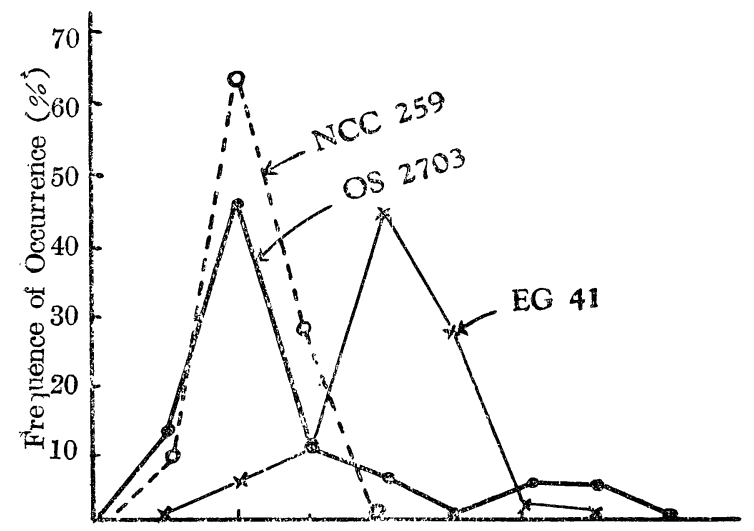

$\begin{array}{lllllllllll}0.19 & 0.22 & 0.25 & 0.28 & 0.31 & 0.34 & 0.37 & 0.40 & 0.43 & 0.46\end{array}$ $\begin{array}{llllllllll}0.21 & 0.24 & 0.27 & 0.30 & 0.33 & 0.36 & 0.39 & 0.42 & 0.45 & 0.48\end{array}$ Coefficient of Friction
コークス系で硬度により眞比重は非常に變化す る.とこに昌スート系とコークス系の差珙を見出 -

を 33 枚，米國ナショナルの $\mathrm{NCC}, 259$ を 30 枚 供江資料己して使用しを。第 32 圖は，其等刷 一の摩擦係数仙現頻度曲線を示し学るのである。 归累率 NCC-259 に就いて見るに, 大部分加

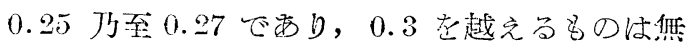

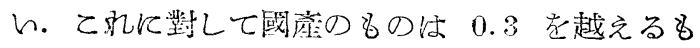

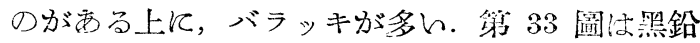

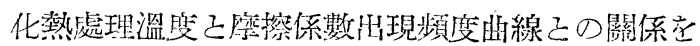

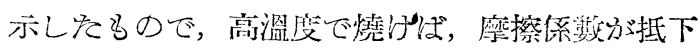
し均一性汃堆划ずる事走示して居る。

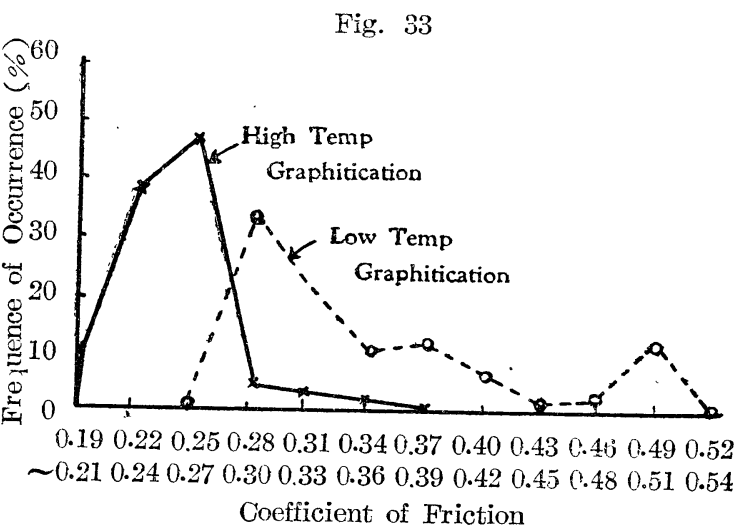

\section{次 號 豫 告}

卷 頭 言

研 究報 告

(1) 電氣朋炭素製品製造儿關する政究（第 9 報） タール炭化のときの混和硫黄の影響 工業技術聽大阪工.試许瀨 元 吉 川崎 政 -

(2) 炭素の着火性に及ぼす監類の影響

東泉大祭教授 赤淞唀雄

總說

(1) 學振に打ける電刷子砄究の業績

前第 117 楚具辰 宗営知行
(2) 炭素及び黑鉛電䣾の日本工業標淮規格案 の解談

炭素工業技闰委員會

講——戔

カーボンブラック

工業技衔臨大阪工試仙不正

㾞 料

G L Neivs 大本敵工提共

其

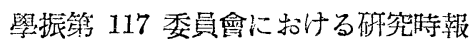

